\title{
Variation in decomposition rates in the fynbos biome, South Africa: the role of plant species and plant stoichiometry
}

\author{
Jan Bengtsson • Charlene Janion • Steven L. Chown • \\ Hans Petter Leinaas
}

Received: 15 June 2009/ Accepted: 9 August 2010/Published online: 9 September 2010

(c) The Author(s) 2010. This article is published with open access at Springerlink.com

\begin{abstract}
Previous studies in the fynbos biome of the Western Cape, South Africa, have suggested that biological decomposition rates in the fynbos vegetation type, on poor soils, may be so low that fire is the main factor contributing to litter breakdown and nutrient release. However, the fynbos biome also comprises vegetation types on more fertile soils, such as the renosterveld. The latter is defined by the shrub Elytropappus rhinocerotis, while the shrub Galenia africana may become dominant in overgrazed areas. We examined decomposition of litter of these two species and the geophyte Watsonia borbonica in patches of renosterveld in an agricultural landscape. In particular, we sought to understand how plant species identity affects litter decomposition rates, especially through variation in litter stoichiometry. Decomposition (organic matter mass loss) varied greatly among the species, and was related to litter $\mathrm{N}$ and $\mathrm{P}$ content. G. africana, with highest nutrient content, lost $65 \%$ of its original mass after 180 days, while
\end{abstract}

Communicated by Michael Madritch.

Electronic supplementary material The online version of this article (doi:10.1007/s00442-010-1753-7) contains supplementary material, which is available to authorized users.

J. Bengtsson $(\bowtie)$

Department of Ecology, Swedish University of Agricultural

Sciences (SLU), Box 7044, 75007 Uppsala, Sweden

e-mail: Jan.Bengtsson@ekol.slu.se

C. Janion $\cdot$ S. L. Chown

Centre for Invasion Biology, Department of Botany and Zoology, , Stellenbosch University, Private Bag X1,

Matieland 7602, South Africa

H. P. Leinaas

Integrative Biology Group, Department of Biology,

University of Oslo, PO Box 1066, 0136 Oslo, Norway
E. rhinocerotis had lost ca. 30\%, and the very nutrient poor $W$. borbonica $<10 \%$. Litter placed under $G$. africana decomposed slightly faster than when placed under $E$. rhinocerotis. Over the course of the experiment, G. africana and E. rhinocerotis lost $\mathrm{N}$ and $\mathrm{P}$, while $W$. borbonica showed strong accumulation of these elements. Decomposition rates of $G$. africana and E. rhinocerotis were substantially higher than those previously reported from fynbos vegetation, and variation among the species investigated was considerable. Our results suggest that fire may not always be the main factor contributing to litter breakdown and nutrient release in the fynbos biome. Thus, biological decomposition has likely been underestimated and, along with small-scale variation in ecosystem processes, would repay further study.

Keywords Ecosystem functioning - Fynbos - Nutrient release $\cdot$ Renosterveld $\cdot$ Soil ecology

\section{Introduction}

In terrestrial systems, plant species composition affects herbivores and decomposers and the processes for which they are responsible. This is mediated at least partly by variation and complexity in plant chemistry due to secondary plant metabolites and plant stoichiometry (Enríquéz et al. 1993; Wardle 2002; Sudderth et al. 2005; Osler and Sommerkorn 2007). Traditionally, nitrogen (N) has been regarded to be the key limiting element in terrestrial systems (Vitousek and Howarth 1991; Ågren and Bosatta 1996), while phosphorus (P) plays a much more important role in limnetic systems (e.g. Schindler 1977). However, production in many terrestrial systems can also be influenced by P-limitation (Elser et al. 2007), especially in 
geologically older areas which never have been subjected to glaciation or aeolian deposits, such as Hawaii (Vitousek 2004) and South Africa (Richards et al. 1997, but see also Witkowski 1989). In addition, even if $\mathrm{N}$ is a limiting factor for primary production in a system, herbivory and litter decomposition processes may still be influenced significantly by other aspects of plant stoichiometry, such as $\mathrm{P}$ content (Hobbie and Vitousek 2000).

Differential effects of species at the scale of individual plants may be important for spatial variation and heterogeneity in ecosystems. It may create a mosaic structure of ecosystem processes even within vegetation types (Usher et al. 1982; Saetre and Bååth 2000; Ettema and Wardle 2002; Whitham et al. 2003). Below-ground variation in the quality and quantity of litter originating from different plant species may contribute to spatial variation in decomposition and nutrient cycling as well as to soil community structure (De Deyn et al. 2004; Wardle 2005; Viketoft et al. 2009). Individual plant species within a vegetation type can in different ways affect microbial communities and thereby decomposition rates on a small scale (Loreau 1998; Ehrenfeld et al. 2005). Decomposer communities may be adapted to litter fall on the spatial scale of individual plants, resulting in higher decomposition rates of a specific litter type under the plant species from which it originates (Ayres et al. 2009). Alternatively, plant species produce litter of different stoichiometry, which in itself may affect decomposition rates substantially (Enríquéz et al. 1993; Sterner and Elser 2002).

The Western Cape of South Africa is characterized by the hyperdiverse vegetation of the fynbos biome (Cowling and Lombard 2002; Linder 2003; Mucina and Rutherford 2006; Thuiller et al. 2006). Typical fynbos vegetation occurs on poor, sandy or stony soils (Mucina and Rutherford 2006). It is characterized by Proteaceae, ericoid shrubs, and the reed-like Restionaceae, which have low nutrient content and produce slowly decomposing litter (Mitchell et al. 1986; Witkowski 1991). Previous studies have suggested that biological decomposition is so low that litter accumulates on the ground for years, until it is consumed by the periodic fires typical of this vegetation type. Consequently, it has been argued that fire is a major factor for litter decomposition and nutrient cycling in fynbos vegetation (Mitchell 1983; Mitchell et al. 1986; Stock and Lewis 1986; Stock and Allsopp 1992).

The fynbos biome, however, also includes other vegetation types, one of the most significant being the renosterveld, which is also fire-prone. It occurs on richer, more developed and clay-rich soils, e.g. in valleys and on river plains, and, in contrast to the typical fynbos vegetation, includes few proteoids, ericoids and restioids (see Mucina and Rutherford 2006). Renosterveld used to constitute about $30 \%$ of the fynbos biome (Mucina and Rutherford
2006), but as it occupied the most fertile soils of Western Cape, it has long been under pressure from agriculture and urban development (Kemper et al. 1999; Rouget et al. 2003). The restricted remains of this formerly extensive vegetation type are highly fragmented and often strongly influenced by grazing from cattle and sheep. The defining plant species of this vegetation type is the renosterbos Elytropappus rhinocerotis (Asteraceae), which is an abundant and conspicuous shrub. Other important elements in this vegetation type are asteraceous shrubs, and a rich geophyte flora (Mucina and Rutherford 2006). Elytropappus rhinocerotis is unpalatable to livestock (Proksch et al. 1982), and thus it may be favoured by grazing, as is certainly true of the yellowbush (Galenia africana), which has become a dominant species in many disturbed and overgrazed areas (van der Lugt et al. 1992; Allsopp 1999).

Generalisations about ecological processes in the fynbos biome, such as the role of fire in litter decomposition (Mitchell et al. 1986; Mitchell and Coley 1987), have largely been based on studies of the typically nutrient-poor fynbos. Much less ecological work has been done in renosterveld (but see, e.g., Donaldson et al. 2002), and very little is known about the belowground processes in this vegetation type (Stock and Allsopp 1992). The differences in plant productivity and soil properties between the typical fynbos and the renosterveld may affect plant stoichiometry and thereby have consequences for decomposition and nutrient dynamics.

In this study, we compare decomposition of litter, measured as mass loss from litter bags, from selected plant species in renosterveld. In particular, we examine to what extent decomposition dynamics of litter from different species can be predicted from their stoichiometry, and the shrub species under which they are placed. We chose to focus on two herbaceous shrubs common to the renosterveld, E. rhinocerotis and G. africana, which both have considerably higher $\mathrm{N}$ and $\mathrm{P}$ content (personal observations) than typical fynbos plants (Mitchell et al. 1986), and also differ between each other in stoichiometry (see below). In addition, we included a geophyte, Watsonia borbonica (Iridaceae), as a representative of the rich geophyte flora typical of renosterveld (Mucina and Rutherford 2006). The results are compared with previous studies of decomposition in fynbos. The study is part of a larger project examining soil animal diversity and ecosystem processes in the fynbos biome.

\section{Materials and methods}

We recorded mass loss of litter placed in the field in small containers (plastic litter bags), designed to examine both soil animals and decomposition, for 6 months during the South African winter in 2007 (March-September). 
Study sites

Two study sites with remnant patches of renosterveld vegetation were chosen in an agricultural landscape north of Piketberg, approximately $200 \mathrm{~km} \mathrm{~N}$ of Cape Town, South Africa. The area has typical Mediterranean climate with cool, moist winters and hot, dry summers (Online Resource, Appendix 1). The two farms, Meerlandsvlei and Renosterhoek, grow mainly wheat and canola. Both also have livestock, grazing being most intense at Renosterhoek. Parts of the farms contain areas with semi-natural vegetation, mainly renosterveld. Although most grazing occurs on the farmed fields, the renosterveld patches were also somewhat affected. Two such patches with both G. africana and E. rhinocerotis bushes were selected. Both study sites were within $50 \mathrm{~m}$ of farmed fields, as most of the patches with natural vegetation in this area are small (from 10 to $200 \mathrm{~m}$ in diameter; mean area approx. $10 \mathrm{ha}$ ).

The site at Renosterhoek $\left(32^{\circ} 32.146^{\prime} \mathrm{S}, 18^{\circ} 49.393^{\prime} \mathrm{E}\right)$ was an approximately 1-ha area that was moderately grazed when the study commenced. The shrub layer was dominated by E. rhinocerotis, interspersed with a large number of G. africana bushes. The ground layer had both grasses and forbs. The Meerlandsvlei site $\left(32^{\circ} 34.189^{\prime} \mathrm{S}\right.$, $18^{\circ} 53.009^{\prime} \mathrm{E}$ ) was a smaller patch, $<0.5 \mathrm{ha}$, and had a more species-rich shrub layer, but with both $G$. africana and E. rhinocerotis occurring commonly. Bare ground was common at both sites during the dry season, but by the end of the study period in August-September, it was largely covered by annual plants, mainly forbs. The size and vegetation of the two selected patches can be considered representative of the large number of small patches with semi-natural vegetation in the renosterveld of the Swartland area north of Cape Town and elsewhere (see Donaldson et al. 2002). None of the sites had burned during the years preceding the study, but on Meerlandsvlei some parts of the patch bordering the wheat fields were accidentally burned in early May, resulting in a loss of traps from two pairs of bushes (see below).

Plant species, litter collection and treatment

Three plant species were chosen for study. Renosterbos, Elytropappus rhinocerotis (Asteraceae), is the defining plant species for the renosterveld vegetation type (Mucina and Rutherford 2006). It is a common, evergreen, resinous shrub, up to $2 \mathrm{~m}$ tall and with scale-like dark green leaves. It occurs on more fertile clay, shale and sandstone soils over much of the Western Cape (Manning 2007). It is rich in phenolics (Proksch et al. 1982), and has been used for infusions in traditional medicine (van Wyk et al. 2000). Its resin exhibits anti-herbivore properties by acting as a tannin-like compound (Proksch et al. 1982). The plant material used in this study was obtained from a stand close to Stellenbosch, and had C:N $=52.4$, and $\mathrm{C}: \mathrm{P}=810$.

Galenia africana (Aizoaceae) is also a common shrub in the Western Cape, up to $1.5 \mathrm{~m}$ tall. It is an indicator of disturbance such as overgrazing (Allsopp 1999; Todd and Hoffmann 1999), has a complex set of secondary compounds and is toxic to sheep and goats (Van der Lugt et al. 1992; Vries et al. 2005). It has been argued to enrich and stabilize soils under its canopy, producing fertile islands with higher levels of nitrogen and available phosphorus (Allsopp 1999; Simons and Allsopp 2007). This species was collected from an overgrazed rangeland west of the Paarl mountain, where it was the dominant shrub in the vegetation. It had a higher nutrient content than E. rhinocerotis $(\mathrm{C}: \mathrm{N}=23.0$, and $\mathrm{C}: \mathrm{P}=367)$.

The geophyte Watsonia borbonica (Iridaceae) is a robust, branched, 50- to $200-\mathrm{cm}$-tall perennial with firm leaves which turn brown by the end of summer. It occurs on sandstone, granite and clay in the southwestern Cape (Manning 2007). The species represents the sturdier elements of the rich geophyte flora in the Western Cape, and may be quite numerous in renosterveld patches (personal observation). Although it is not listed by Mucina and Rutherford (2006) as a species typical of renosterveld in the Piketberg area, the similar, congeneric geophyte, Watsonia marginata, is an important element in this area. However, for conservation reasons, we did not include material of this species, nor of representatives of the shortlived seasonal or annual geophytes, most of which flower in spring and disappear shortly afterwards. Watsonia borbonica litter was collected in an area dominated by this species in the Jonkershoek Nature Reserve, $10 \mathrm{~km} \mathrm{SE}$ of Stellenbosch. It had the lowest nutrient content of the three studied species $(\mathrm{C}: \mathrm{N}=133$, and $\mathrm{C}: \mathrm{P}=8,277)$. The chemical composition of all plant materials used is given in Online Resource, Appendix 2.

Plant material of E. rhinocerotis and G. africana was collected on 6-7 March 2007, at the end of the dry season, by cutting the outer $10-20 \mathrm{~cm}$ of branches of healthy shrubs. The material was taken to the laboratory, dried at $40^{\circ} \mathrm{C}$ for at least $24 \mathrm{~h}$, and then stored in open containers at room temperature. We separated the leaves and outermost $(1-2 \mathrm{~cm})$ thin branches from the coarser material, and cut this into approximately $1-\mathrm{cm}$-long pieces. Watsonia borbonica was collected on 7 March by taking whole leaves from the plants. The leaves were cut into approx. $1 \times 1 \mathrm{~cm}$ pieces and dried at room temperature for 5 days. For each species, the air-dried litter was mixed thoroughly and then stored dry at room temperature until placed in the litter bags. To estimate initial nutrient content, dry mass and ashfree dry mass, six randomly selected samples of each species were taken when the litter bag traps were being filled. 
The litterbags constituted individually numbered cylindrical plastic containers with a height of $4 \mathrm{~cm}$ and a diameter of $7.5 \mathrm{~cm}$. The bottom consisted of a steel net with mesh size $0.5 \mathrm{~mm}$. The traps had a removable lid with 1.6-mm mesh size to allow animals to enter the trap. In the laboratory, the traps were filled with air-dried litter up to approx. $3.5 \mathrm{~cm}$, which had been weighed to nearest $0.1 \mathrm{mg}$ on an electronic balance (FA304T; Avery Berkel, Fairmont, USA). The litter was not compressed and was allowed to maintain its normal volume and density. Average litter dry mass per trap was: G. africana $16.33 \mathrm{~g}$ (range 15.38-17.34), E. rhinocerotis $9.91 \mathrm{~g}$ (range 9.42-10.51) and W. borbonica $8.76 \mathrm{~g}$ (range 8.09-9.57), corresponding to on average $13.81,9.51$ and $8.54 \mathrm{~g}$ of organic matter, respectively. The filled traps were stored dry at room temperature before being deployed in the field on 14 March 2007.

\section{Experimental design}

To examine the differences in decomposition rate and nutrient dynamics among the three litter types, and to test if there was effect of the bush species under which litter was placed on decomposition rate, we placed three sets of three litterbag traps under five bushes of G. africana and five bushes of E. rhinocerotis at each of the two sites. Each set contained one trap of each litter type. The bushes were chosen to ensure that both bush species were interspersed over the whole study site, to avoid confounding the bush effect with unmeasured environmental gradients. Coordinates for each bush was obtained by GPS.

The traps were placed under the bushes, less than $40 \mathrm{~cm}$ from the bush base, on the southwest to southeast side to minimise sun exposure. They were placed in the soil with the top of the trap at ground level. The traps in each set were placed within 3-4 cm from each other, while the distance between sets under a bush was at least $10 \mathrm{~cm}$.

An accidental burning destroyed 24 of the traps at Meerlandsvlei. In addition, 4 traps at Renosterhoek were dug up by animals, 4 traps were flooded at Meerlandsvlei, and 4 traps were lost for unknown reasons. The data set thus comprises 146 of the original 180 traps, but the losses were not much more common for one litter type or bush species (Table 1).

\section{Collection of traps and laboratory treatment}

To examine mass loss variation over the season, the litterbags were sampled at three times: 18 May, 27 July and 12 September 2007, i.e. after 65, 131 and 182 days in the field. At each sampling period, one randomly selected set of traps was collected from each bush, while the remainder were left for later collection. When traps were collected, they were
Table 1 Decomposition rate ( $k$ values) of litter of the three renosterveld plant species, Galenia africana (G), renosterbos Elytropappus rhinocerotis $(\mathrm{R})$ and Watsonia borbonica $(\mathrm{W})$

\begin{tabular}{lllllll}
\hline Litter type & $k$ value $\left(\right.$ day $\left.^{-1}\right)$ & SE & $n$ & $\begin{array}{l}\text { Half-life } \\
\text { (days) }\end{array}$ & SE & $n$ \\
\hline $\mathrm{G}$ & 0.00674 & 0.00012 & 50 & 101.2 & 151.5 & 36 \\
$\mathrm{R}$ & 0.00222 & 0.00012 & 47 & 308.4 & 151.5 & 34 \\
$\mathrm{~W}$ & 0.00029 & 0.00012 & 49 & 2,032 & 151.5 & 35 \\
\hline
\end{tabular}

Values are mean $k$ values (decomposition constant in the exponential decay model; unit $\mathrm{g} \mathrm{g}^{-1}$ organic matter day ${ }^{-1}$ ) and mean mass halflife (in days) for the three litter types across the three sampling days. Only the effect of litter type is shown because variation due to this factor was far greater than for all other factors (as shown in Table 2). Half-life values do not include data from sampling day 65 because of a number of negative mass loss values for $W$. borbonica (indicating increased mass; see text)

taken out of the soil, wrapped in aluminium foil and immediately placed individually in plastic bags and stored cool, in an upright position in thermally insulated containers, until they were returned to the laboratory on the same evening. They were then stored at $8-10^{\circ} \mathrm{C}$ for $1-7$ days.

Before chemical analysis, soil animals were extracted from the samples (results not presented here). The dry litter samples in each trap were then gently transferred to aluminium foil and dried at $50^{\circ}$ for at least $24 \mathrm{~h}$ to ensure that the samples were dry before storage. Little organic material was lost during the extraction process. The dried samples were individually packed in aluminum foil and plastic bags, and sent to Sweden for determination of mass loss and chemical composition.

Mass loss was determined as loss of organic matter from the traps. Dry weight was determined by weighing samples before and after heating at $105^{\circ} \mathrm{C}$ for $24 \mathrm{~h}$. Ash-free dry weight was determined after heating at $550^{\circ} \mathrm{C}$. The difference between ash-free dry weight and dry weight was used as the measure of organic matter in the material. Many traps had accumulated mineral soil particles during the study period, which was accounted for by this procedure.

Total $\mathrm{C}$ and $\mathrm{N}$ concentrations in the dried material were determined using a Carlo-Erba NA 1500 Elemental Analyzer (Strumentazione, Milan, Italy). Phosphorus (P) and $\mathrm{K}, \mathrm{Na}, \mathrm{Mg}$ and $\mathrm{Ca}$ were measured by Inductively Coupled Plasma Atomic Spectroscopy (Optima 3000; PerkinElmer, Waltham, MA, USA) after wet combustion of $400 \mathrm{mg}$ ground material in nitric and percloric acid.

\section{Statistics}

Mass loss of organic matter was measured by the decomposition constant $k$ calculated assuming the exponential decomposition model (Olson 1963), i.e.

$W_{t}=W_{0} \mathrm{e}^{-k t}$ 
where $W_{0}$ is the mass of organic matter at the start of the experiment and $W_{t}$ is the mass of organic matter at time $t$. The constant $k$ has the unit day ${ }^{-1}$ and was calculated for each litter bag for each sampling day, which was the variable used in the statistical analysis. We also calculated half-life of litter $0.693 k^{-1}$, turnover time of litter $k^{-1}$, and the proportion of organic matter lost at each sampling day (Olson 1963). Carbon to nutrient ratios were calculated on a weight basis using the data from the chemical analyses. All ratios were square-root-transformed before statistical analysis, while $k$ values were untransformed.

We analysed the data with a General Linear Mixed Model (GLMM) using SAS procedure Mixed. The fixed factors in the model were at level 1 Farm, Bush species and their interaction Farm $\times$ Bush species, at level 2 Litter type and its interactions with the above factors, and at level 3 Sampling day and its interactions with all the factors above. The error term when testing effects of factors at level 1 was Farm $\times$ Bush species $\times$ Bush number, at level 2 the error term was Litter $\times$ Farm $\times$ Bush species $\times$ Bush number, and at level 3 the residual error. The full model is given in Table 2, and was used for all dependent variables. Degrees of freedom were estimated with the Satterthwaite method.

\section{Results}

\section{Decomposition}

Litter type was by far the most important factor explaining variation in decomposition rate, measured as loss of organic matter from the litterbags (Tables 1, 2). Galenia africana litter decomposed most rapidly, with less than $40 \%$ of the original organic matter mass remaining after 131 days, but with little further decomposition in the following months (Fig. 1). By contrast, E. rhinocerotis had lost ca. $30 \%$ of the original mass after 182 days, while the $W$. borbonica litter had decomposed very slowly with less than $10 \%$ of the original mass lost at the end of the study. In fact, the amount of organic material in $W$. borbonica litterbags increased slightly during the first time period (from March to May, Fig. 1; one-sample $t$ test if mass loss is negative and differs from $0, p=0.0085, n=14$ ) and decreased only from May onwards.

Half-life of litter ranged from 100 days for G. africana to more than 5 years for $W$. borbonica litter (Table 1). Turnover of litter was 0.4 years for $G$. africana, 1.2 years for E. rhinocerotis and 8.6 years for W. borbonica. However, because these values were calculated for the first 182 days of decomposition only, the degree of uncertainty in the estimates is fairly high, with the exception of the fast decomposing G. africana.

The temporal pattern in decomposition rates ( $k$ values) during the experiment differed between species, as indicated by the significant Litter type $\times$ Sampling day interaction (Table 2). All litter types showed an increase in decomposition rate from May to July (Days 65-131; data not shown). However, G. africana then showed a subsequent strong decrease in decomposition rate from July to September (Days 131-182; Fig 1). Evidently, most of the

Table 2 Statistical (GLMM) analysis of decomposition rate in relation to the fixed factors farm, bush species, litter type and sampling day

\begin{tabular}{|c|c|c|c|}
\hline Factor & $d f$ & $F$ & $P$ \\
\hline Farm & 14.6 & 2.75 & 0.1183 \\
\hline Bush species & 14.6 & 2.38 & 0.1440 \\
\hline Bush species $\times$ Farm & 14.6 & 4.18 & 0.0593 \\
\hline Litter type & 29.5 & $1,108.4$ & $<0.0001$ \\
\hline Litter type $\times$ Bush species & 29.5 & 0.06 & 0.9411 \\
\hline Litter type $\times$ Farm & 29.5 & 2.82 & 0.0756 \\
\hline Litter type $\times$ Bush species $\times$ Farm & 29.5 & 2.71 & 0.0833 \\
\hline Sampling day & 77.1 & 30.84 & $<0.0001$ \\
\hline Sampling day $\times$ Bush species & 77.1 & 0.87 & 0.4212 \\
\hline Sampling day $\times$ Farm & 77.1 & 0.88 & 0.4178 \\
\hline Sampling day $\times$ Bush species $\times$ Farm & 77.1 & 1.27 & 0.2873 \\
\hline Litter type $\times$ Sampling day & 79.2 & 13.69 & $<0.0001$ \\
\hline Litter type $\times$ Bush species $\times$ Sampling day & 79.2 & 0.39 & 0.8169 \\
\hline Litter type $\times$ Farm $\times$ Sampling day & 79.2 & 0.53 & 0.7170 \\
\hline Litter type $\times$ Bush species $\times$ Farm $\times$ Sampling day & 79.2 & 1.25 & 0.2971 \\
\hline
\end{tabular}

The table shows the results from a General Linear Mixed Model analysis of the decomposition constant $(k$ values in Table 1) in relation to the fixed factors Farm, Bush species (i.e. the bush species under which litters were placed; G. africana or E. rhinocerotis), Litter type (i.e. the litter collected from the three species G. africana, E. rhinocerotis or W. borbonica) and Sampling day (65, 131 or 182 days from the start of the experiment) 


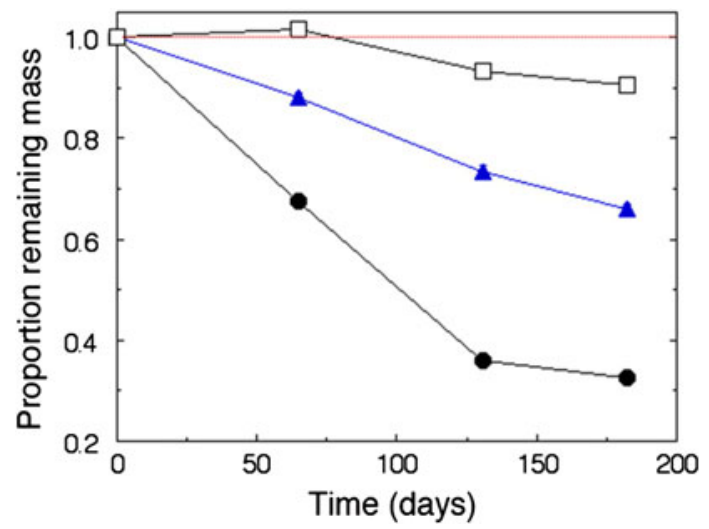

Fig. 1 Mass loss in three litter types in relation to time during the South African winter 2007. Galenia africana (filled dots), renosterbos Elythropappus rhinocerotis (filled triangles) and Watsonia borbonica (open squares). Mass loss differed significantly between the litter types (Tables 1 and 2). Day $0=14$ March 2007. Standard error bars are smaller than the dots

most readily decomposed parts of this litter had disappeared well before the last sampling day.

There was no indication that decomposition was slower when litter of one species was placed under plants of another species. The Bush species $\times$ Litter type interaction was far from significant in the analyses of decomposition rate (e.g. Table 2). On the contrary, decomposition of all litters appeared to be somewhat faster (on average 8\%) when placed under G. africana than under E. rhinocerotis, but the effect varied between the two farms as reflected in the Bush species $\times$ Farm interaction term (Table 2).

Figure 2 shows the relations between initial plant material chemical composition and mass loss. Galenia africana, which decomposed fastest, had the highest initial concentrations of $\mathrm{N}, \mathrm{P}, \mathrm{Na}$ and $\mathrm{Mg}$ while the very slowly decomposing brown $W$. borbonica had by far the lowest concentration of the same nutrient elements. Furthermore, the intermediate litter type, E. rhinocerotis, followed similar relationships between the concentrations of these elements and their decomposition rates. To summarise, we found lower mass loss with increasing $\mathrm{C} / \mathrm{N}$ and $\mathrm{C} / \mathrm{P}$ ratios, as well as for $\mathrm{C} / \mathrm{Na}$ and $\mathrm{C} / \mathrm{Mg}$ ratios, while initial $\mathrm{C} / \mathrm{K}$ and $\mathrm{C} / \mathrm{Ca}$ ratios showed no clear relation to mass loss.

Stoichiometry during decomposition

Plant litter stoichiometry showed significant temporal changes in all litter types. It also differed substantially between litter types (Fig. 3; Online Resource, Appendices 2-3). In all litter types, $\mathrm{N}$ and $\mathrm{P}$ concentrations increased over time, as shown by the decreasing $\mathrm{C} / \mathrm{N}$ and $\mathrm{C} / \mathrm{P}$ ratios (Fig. 3a, b). This was most evident in $W$. borbonica litter, and in particular for the C/P ratio (Fig. 3b). The patterns of
Fig. 2 Remaining mass at the end of the study period (day $182)$ in relation to carbon to nutrient ratios of the original material. a $\mathrm{C} / \mathrm{N}$, b $\mathrm{C} / \mathrm{P}, \mathbf{c} \mathrm{C} / \mathrm{K}$ and $\mathrm{C} / \mathrm{Na}$, and $\mathbf{d} \mathrm{C} / \mathrm{Ca}$ and $\mathrm{C} / \mathrm{Mg}$. Notation: a and b Galenia africana (filled dots), renosterbos Elythropappus rhinocerotis (filled triangles) and Watsonia borbonica (open squares); $\mathbf{c}$ and $\mathbf{d}$ as above for $\mathrm{K}$ and $\mathrm{Ca}$, while for $\mathrm{Na}$ and $\mathrm{Mg}$ the dots are connected by lines, and G. africana (open dot), E. rhinocerotis (open triangle) and $W$. borbonica (filled square), Standard error bars are smaller than the dots
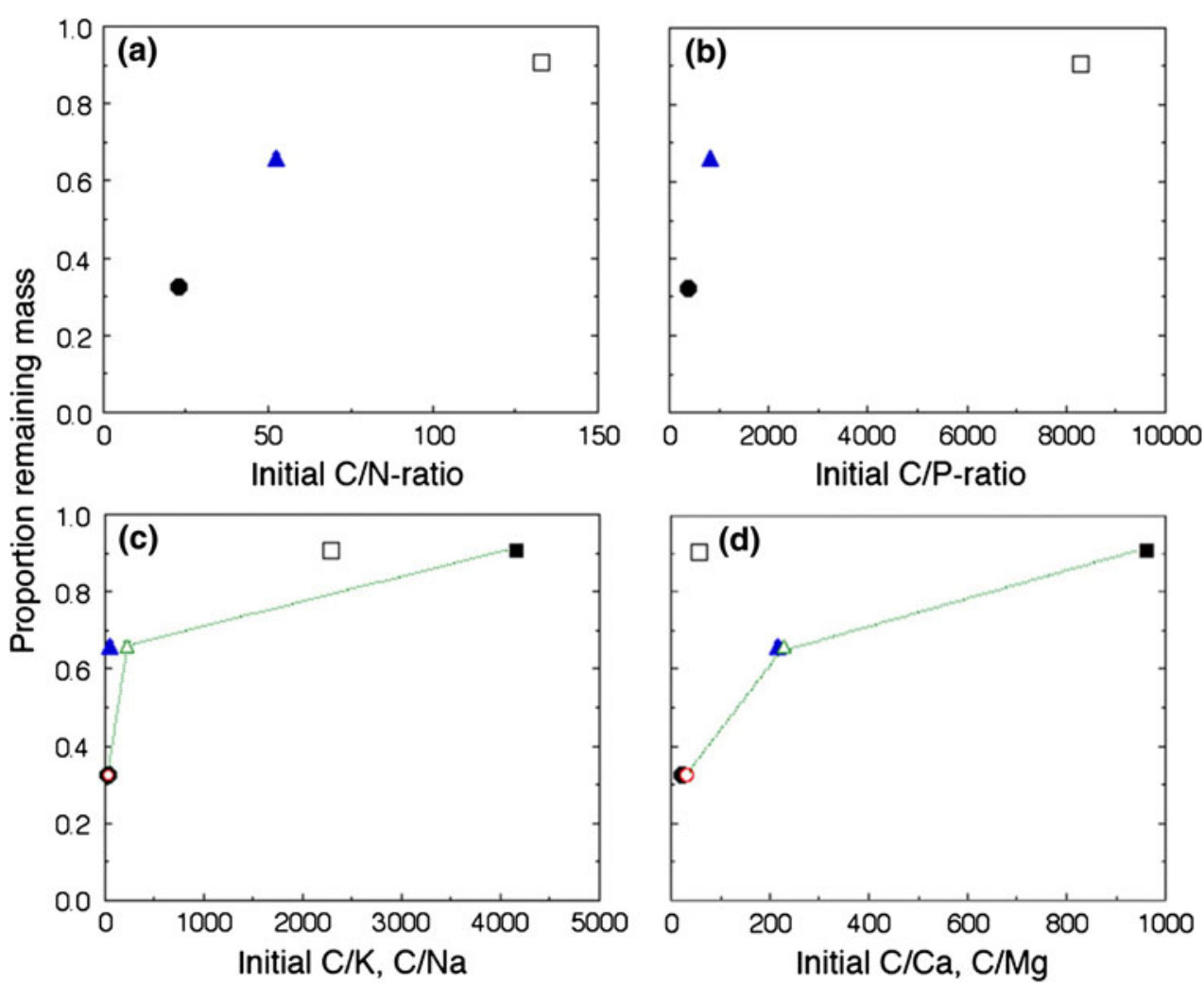
change in $\mathrm{K}, \mathrm{Na}, \mathrm{Mg}$ and $\mathrm{Ca}$ varied between the four elements and four litter types. $\mathrm{C} / \mathrm{K}$ and $\mathrm{C} / \mathrm{Na}$ ratios increased with time in G. africana and E. rhinocerotis, indicating higher losses of these elements than expected from mass loss. By contrast, W. borbonica litter showed decreasing $\mathrm{C} / \mathrm{K}$ and $\mathrm{C} / \mathrm{Na}$ ratios over time (Fig. 3c, f). Decreased $\mathrm{C} / \mathrm{Mg}$ ratios over time were found for all litter types except $G$. africana (Fig. 3e). Levels of and changes in $\mathrm{C} / \mathrm{Ca}$ appeared to be unrelated to the other elements. G. africana litter showed the lowest $\mathrm{C} / \mathrm{Ca}$ ratios, as expected, but $W$. borbonica litter had lower $\mathrm{C} / \mathrm{Ca}$ ratios than E. rhinocerotis, which was the most $\mathrm{Ca}$ poor litter during the whole study period (Fig. 3f).

The plant litter types varied in the dynamics of $\mathrm{N}$ and $\mathrm{P}$ (Fig. 4). In G. africana litter, despite a decrease in $\mathrm{C} / \mathrm{N}$ ratio, more than half of the original nitrogen $(57 \%)$ had been mineralised and lost from the litterbags during the study period. Much less nitrogen had been mineralised from E. rhinocerotis litter (15\%) while in the W. borbonica litter, $\mathrm{N}$ had accumulated during the same period (Fig. 4a). Similarly, there had been a marked loss of P from G. africana and E. rhinocerotis litter. The brown W. borbonica litter differed fundamentally from the other litter types by a strong accumulation of $\mathrm{P}$, that must have been obtained from the surroundings (Fig. 4b). Nutrient concentrations were higher in litter placed under G. africana bushes than in litter placed under E. rhinocerotis (Online Resource, Appendix 3).

\section{Discussion}

Earlier studies have suggested that decomposition of typical fynbos plants is very slow (Mitchell et al. 1986; Mitchell and Coley 1987; Witkowski 1991; Stock and Allsopp 1992). Our study showed considerably higher decomposition rates than found in these previous studies (Table 3). One possible explanation for these contrasting results is that decomposition is generally faster in the more nutrient-rich renosterveld than in typical fynbos vegetation, which grows on nutrient-poor soils (e.g. Witkowski 1991; Mucina and Rutherford 2006; Manning 2007). However,

Fig. 3 Temporal changes in carbon to nutrient ratios in three litter types: Galenia africana (G, filled dots), renosterbos Elythropappus rhinocerotis ( $\mathrm{R}$, filled triangles) and Watsonia borbonica (W, open squares). See Online Resource, Appendix 3 for results from statistical analyes. Standard error bars when not visible are smaller than the dots. a $\mathrm{C} / \mathrm{N}$-ratio in litter types $\mathrm{G}, \mathrm{R}$ and $\mathrm{W}$ decreased with time. b C/P-ratio in litter types $\mathrm{G}, \mathrm{R}$ and $\mathrm{W}$ decreased with time. c $\mathrm{C} / \mathrm{K}$-ratio in $\mathrm{G}$ and $\mathrm{R}$ increased with time, while it decresed in $\mathrm{W}$. d C/Ca-ratio in all litter types decreased with time. e C/Mg-ratio in $\mathrm{R}$ and $\mathrm{W}$ decreased with time, but did not change in $\mathrm{G}$. $\mathbf{f ~ C / N a - r a t i o ~ i n ~} \mathrm{G}$ and $\mathrm{R}$ increased with time while $\mathrm{W}$ decreased
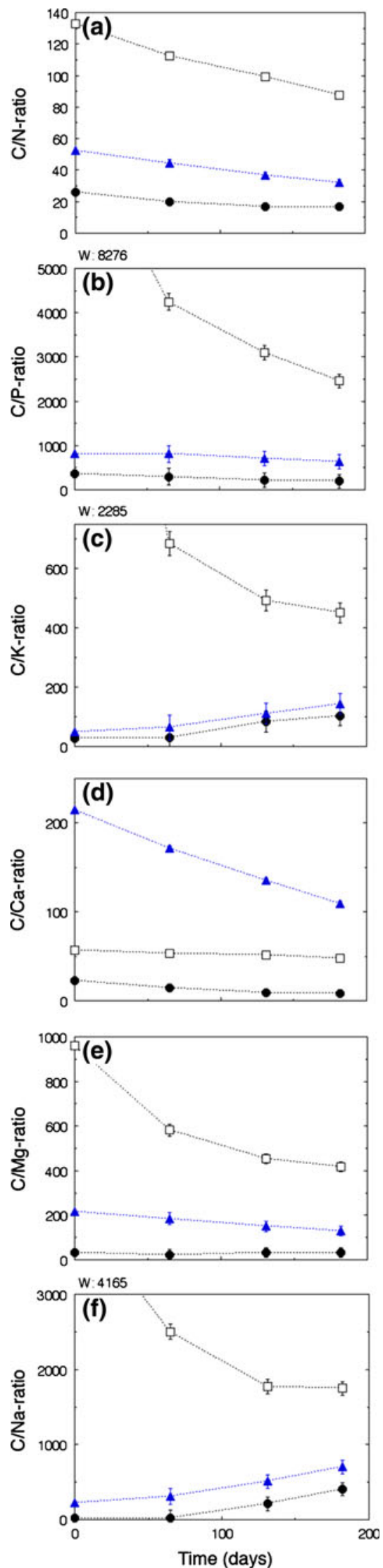


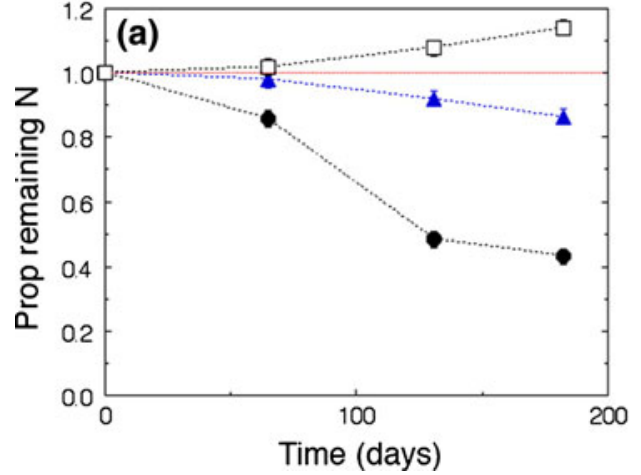

Fig. 4 Changes in proportion of original amounts of $\mathbf{a} \mathrm{N}$ and $\mathbf{b} \mathrm{P}$ in litterbags over time. Galenia africana (filled dots), renosterbos Elythropappus rhinocerotis (filled triangles) and Watsonia borbonica (open squares). The proportion of initial $\mathrm{N}$ and initial $\mathrm{P}$ remaining

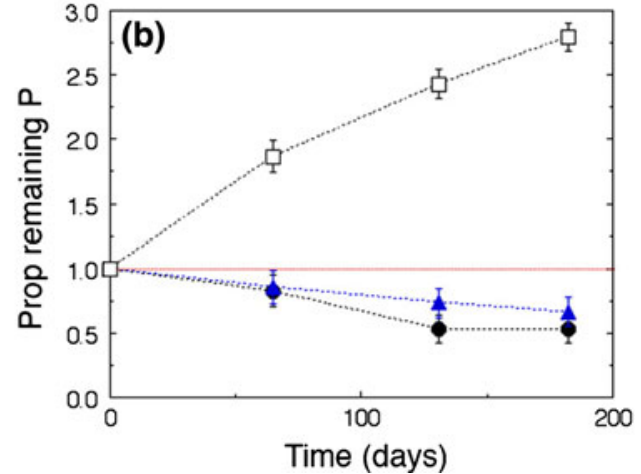

differed between litter types and decreased in G. africana and E. rhinocerotis but increased in $W$. borbonica ( $p<0.05$ in all cases). Standard error bars when not visible are smaller than the dots

Table 3 Decomposition rates $(k)$ and half-life of litter of South African fynbos and renosterveld species

\begin{tabular}{|c|c|c|c|c|}
\hline Species & Vegetation type & $k$ value $\left(\right.$ day $\left.^{-1}\right)$ & Half-life (days) & Source \\
\hline Galenia africana & Renosterveld & 0.00674 & 101 & 1 \\
\hline Elythropappus rhinocerotis & Renosterveld & 0.00222 & 308 & 1 \\
\hline Watsonia borbonica & Fynbos/renosterveld & 0.00029 & 2,032 & 1 \\
\hline Leucospermum parile & Lowland fynbos & 0.00080 & 887 & 2 \\
\hline Leucospermum parile & Lowland fynbos & 0.00065 & 1,062 & 3 \\
\hline Pterocelastrus tricuspidatus & Strandveld & 0.00051 & 1,366 & 3 \\
\hline Protea repens & Lowland fynbos & 0.00013 & 5,161 & 4 \\
\hline Protea repens & Mountain fynbos & 0.00018 & 3,778 & 4 \\
\hline
\end{tabular}

Data from this study (1) and the literature (2-4)

1 this study; 2 Mitchell et al. (1986). Calculated from data on ash-free dry mass loss; 3 Witkowski (1991). Calculated from turnover time; 4 Mitchell and Coley (1987). Calculated from dry mass half-life

these differences could also be a consequence of the fact that only a few, typically proteoid species in fynbos vegetation have been investigated. Thus, it is possible that decomposition is also much more variable (i.e. with some species having half-lives similar to those we found for $G$. africana and E. rhinocerotis) in the typical fynbos vegetation than the few studies undertaken to date suggest.

Such an assumption also seems plausible given that decomposition was highly variable among the renosterveld species investigated here (Table 3). In fact, G. africana and E. rhinocerotis show decomposition rates within the range of shrubs and deciduous trees in other biomes (see Fig. 1 in Enríquéz et al. 1993). In contrast, the half-life of W. borbonica litter was more similar to the previously studied Proteid shrub species in fynbos, such as Protea and Leucospermum (Table 3), which is extremely slow compared to the decomposition rates presented in Enríquéz et al. (1993).

Our results suggest that decomposition processes in the fynbos biome are more complex and variable than indicated by previous studies, as anticipated by, e.g., Mitchell (1983) and Stock and Allsopp (1992). The results also question the previous generalisation that fire is the main factor contributing to litter breakdown and nutrient release in this biome (Mitchell et al. 1986). Although it is obvious that fire must play an important role in decomposition in some years, especially for species with long half-lives, such as the proteoids and W. borbonica, the considerable diversity of species and higher taxa within a given area of fynbos (e.g. Cowling et al. 1997; Cowling and Lombard 2002) indicates that biological decomposition by soil fauna and microbial communities has likely been underestimated, as earlier suggested by Marion (1982). For instance, assuming a fire interval of about 11 years, the estimated average for fynbos systems (van Wilgen 2009), the decomposition rates measured in our study would imply that that biological decomposition accounted for more than $80 \%$ of the removal of G. africana litter, but only about $30 \%$ of $W$. borbonica. This is, of course, a rough estimate, but it emphasises that a better 
understanding of decomposition in this biome requires studies relating this process to variation in plant species identity and nutrient composition within and among vegetation types. Also, differential fire frequencies and the nutrient status of soils need to be taken into account. In particular, there is a need to study the contribution from short-lived seasonal or annual plants to biological decomposition rates.

In this study, plant litter with higher nutrient contents decomposed faster (Fig. 2). Such a relation with initial nutrient content has been documented in numerous previous studies (e.g. Enríquéz et al. 1993; Sterner and Elser 2002). During decomposition, $\mathrm{C} / \mathrm{N}$ and $\mathrm{C} / \mathrm{P}$ ratios decreased in all litter types. This increase in litter nutrient concentration is primarily a function of respiration (carbonuse efficiency) and the degree of nutrient uptake and immobilization by decomposers, which both depend on litter quality (nutrient content) (Manzoni et al. 2008). Consequently, the increase in concentration was strongest in the nutrient poor brown $W$. borbonica. This mechanism has been well documented for $\mathrm{N}$-mineralisation (Manzoni et al. 2008), but we here show an even more pronounced effect on $\mathrm{P}$.

The effect of litter quality becomes even more clear when considering the total amount of nutrient remaining in the litter rather than the concentration (Fig. 4 vs. Fig. 3). In the two nutrient rich litters, nitrogen and phosphorus was mineralised and lost from the litter bags into the soil. By contrast, in the extremely nutrient poor W. borbonica, these elements actually accumulated in the litter bags throughout the experimental period. Hence, there was a net transportation from the surroundings into the litter bags, possibly because of fungal activity (Staaf and Berg 1982; Lindahl and Olsson 2004). Alternatively, passive transportation (leakage) of nutrients from the surrounding soil could have occurred. In the present case, the fact that W. borbonica litter bags actually increased in mass of organic matter during the first 65 days supports the first suggestion. In any case, it seems likely that an increased concentration of nutrients was important to initiate the delayed decomposition in this species and that the mineralised nutrients subsequently were taken up; i.e. immobilised by the decomposers. In another study of the fynbos plant Leucospermum parile, a slight increase in $\mathrm{P}$ content during the first year of decomposition was observed (Mitchell et al. 1986). The concentrations of $\mathrm{K}, \mathrm{Na}$ and $\mathrm{Mg}$ in W. borbonica showed similar increases during decomposition as did $\mathrm{N}$ and $\mathrm{P}$. By contrast, in the two litters with high decomposition rates, concentrations of $\mathrm{K}$ and $\mathrm{Na}$ decreased during the study period, probably because they are easily dissolvable. The different behaviour of $\mathrm{C} / \mathrm{Ca}$ ratios was not related to mass loss.
Galenia africana contains secondary compounds that are toxic to grazers (Van der Lugt et al. 1992; Vries et al. 2005). Nevertheless, it was the most easily decomposed litter, indicating that secondary compounds may not inhibit decomposition processes, possibly because qualitative chemical defences occur in low concentrations in litter and are fairly easily decomposed or leached out of the litter (Schonholzer et al. 1998).

Plant species effects on decomposer communities have commonly been observed on the spatial scale of a few metres (e.g. Saetre and Bååth 2000; Ettema and Wardle 2002; Viketoft et al. 2005). We found no evidence for the 'home-field advantage' hypothesis among decomposer communities (e.g. Ayres et al. 2009) that litter of a species would decompose faster under bushes of the same species than when placed under bushes of another species. This holds for both the defining species of renosterveld (E. rhinocerotis), as well as for one of the most important indicators of disturbance in this vegetation type (G. africana). Thus, these decomposer communities do not seem to be adapted to the litter of a particular plant species at the scale of single shrub individuals. This is consistent with previous conclusions by Wardle (2005) and Ehrenfeld et al. (2005). By contrast, all plant litter types tended to decompose slightly faster under G. africana than under E. rhinocerotis. This could be a consequence of more suitable microclimate conditions for decomposition under G. africana. Another reason could be related to the fact that nutrient conditions have been suggested to increase under $G$. africana bushes (Allsopp 1999). This suggestion is supported by our finding that litter placed under G. africana had higher nutrient concentrations than litter placed under E. rhinocerotis (Online Resource, Appendix 3). Hence, all else being equal, microbial decomposers may be more active under $G$. africana resulting in a slightly higher decomposition rate.

\section{Conclusions}

Our results suggest that litter decomposition rates in the fynbos biome may be more variable than indicated by previous studies, which were confined to fynbos vegetation. There seems to be considerable variation between the renosterveld and fynbos vegetation, but also between different litter types within these vegetation types. Thus, previous generalisations regarding the key role of fire for decomposition processes in this biome may need to be revisited. Finally, our study addressed the 'home-field advantage' hypothesis among decomposer communities in renosterveld, but we did not find any evidence that these are adapted to the dominant plant species at the scale of single plant individuals. 
Acknowledgments We thank Joachim Strengbom and two anonymous reviewers for comments on the manuscript, Birgitta Vegerfors for statistical advice, David Richardson and Suzaan KritzingerKlopper for discussion, identification and other help with the plant species, Thomas Grönqvist for chemical analyses, and the farmers, especially the Rossouw family, for hospitality and allowing access to their land. Funded by SA-Norway Grant 180349 to S.L. Chown/H.P. Leinaas from the Norwegian Research Council and a South AfricaSIDA/VR grant from the Swedish Research Council to S.L. Chown and J. Bengtsson. The authors declare that they have no conflict of interest.

Open Access This article is distributed under the terms of the Creative Commons Attribution Noncommercial License which permits any noncommercial use, distribution, and reproduction in any medium, provided the original author(s) and source are credited.

\section{References}

Ågren GI, Bosatta E (1996) Theoretical ecosystem ecology, understanding element cycles. Cambridge Univiversity Press, Cambridge

Allsopp N (1999) Effects of grazing and cultivation on soil patterns and processes in the Paulshoek area of Namaqualand. Plant Ecol 142:179-187

Ayres E, Steltzer H, Simmons BL, Simpson RT, Steinweg JM, Wallenstein MD, Mellor N, Parton WJ, Moore JC, Wall DH (2009) Home-field advantage accelerates leaf litter decomposition in forests. Soil Biol Biochem 41:606-610

Cowling RM, Lombard AT (2002) Heterogeneity, speciation/extinction history and climate: explaining regional plant diversity patterns in the Cape Floristic Region. Diversity Distrib 8:163-179

Cowling RM, Richardson DM, Muster PJ (1997) Fynbos. In: Cowling RM, Richardson DM, Pierce SM (eds) The vegetation of southern Africa. Cambridge University Press, Cambridge, pp 99-130

de Deyn GB, Raaijmakers CE, van Ruijven J, Berendse F, van der Putten WH (2004) Plant species identity and diversity effects on different trophic levels of nematodes in the soil food web. Oikos 106:576-586

Donaldson J, Nänni I, Zachariades C, Kemper J (2002) Effects of habitat fragmentation on pollinator diversity and plant reproductive success in renosterveld shrublands of South Africa. Cons Biol 16:1267-1276

Ehrenfeld JG, Ravit B, Elgersma K (2005) Feedback in the plant-soil system. Annu Rev Environ Resour 30:75-115

Elser JJ, Bracken MES, Cleland EE, Gruner DS, Harpole WS, Hillebrand H, Ngai JT, Seabloom EW, Shurin JB, Smith JE (2007) Global analysis of nitrogen and phophorus limitation of primary producers in freshwater, marine and terrestrial ecosystems. Ecol Lett 10:1135-1142

Enríquéz S, Duarte CM, Sand-Jensen K (1993) Patterns in decomposition rates among photosynthetic organisms: the importance of detritus C:N:P content. Oecologia 94:457-471

Ettema CH, Wardle DA (2002) Spatial soil ecology. Trends Ecol Evol 17:177-183

Hobbie SE, Vitousek PM (2000) Nutrient limitation of decomposition in Hawaiian forests. Ecology 81:1867-1877

Kemper J, Cowling RM, Richardson DM (1999) Fragmentation of South African renosterveld shrublands: effects on plant community structure and conservation implications. Biol Cons 90:103-111
Lindahl BD, Olsson S (2004) Fungal translocation-creating and responding to environmental heterogeneity. Mycologist 18:79-88

Linder HP (2003) The radiation of the Cape flora, southern Africa. Biol Rev 78:597-638

Loreau M (1998) Biodiversity and ecosystem functioning: a mechanistic model. Proc Natl Acad Sci USA 95:5632-5636

Manning J (2007) Field guide to fynbos. Struik, Cape Town

Manzoni S, Jackson RB, Trofymow JA, Porporato A (2008) The global stoichiometry of litter nitrogen mineralization. Science 321:684-686

Marion GM (1982) Nutrient mineralisation processes in mediterranean-type ecosystems. In: Conrad CE, Oechel WC (eds) Proceedings of the symposium on dynamics and management of mediterranean-type ecosystems. San Diego, California, pp 313-320

Mitchell DT (1983) Section 3, nutrient cycling. In: Kruger FJ, Mitchell DT, Jarvis JUM (eds) Mediterranean type ecosystems. The role of nutrients. Ecological studies 43. Springer, Berlin, pp 177-178

Mitchell DT, Coley PGF (1987) Litter production and decompositions from shrubs of Protea repens growing in sand plain lowland and mountain fynbos, south-western Cape. S Afr J Bot 53:25-31

Mitchell DT, Coley PGF, Webb S, Allsopp N (1986) Litter fall and decomposition processes in the coastal fynbos vegetation, southwestern Cape, South Africa. J Ecol 74:977-993

Mucina L, Rutherford MC (eds) (2006) The vegetation of South Africa, Lesotho and Swaziland. Strelitzia 19. South African National Biodiversity Institute, Pretoria

Olson JS (1963) Energy storage and the balance of producers and decomposers in ecological systems. Ecology 44:322-331

Osler GHR, Sommerkorn M (2007) Toward a complete soil C and N cycle: incorporating the soil fauna. Ecology 88:1611-1621

Proksch P, Proksch M, Rundel PW, Rodriguez W (1982) Ecological significance of the chemistry of the leaf resin of Elytropappus rhinocerotis. Biochem Syst Ecol 10:49-53

Richards MB, Stock WD, Cowling RM (1997) Soil nutrient dynamics and community boundaries in the fynbos vegetation of South Africa. Plant Ecol 130:143-153

Rouget M, Richardson DM, Cowling RM, Lloyd JW, Lombard AT (2003) Current patterns of habitat transformation and future threats to biodiversity in terrestrial ecosystems of the Cape Floristic Region, South Africa. Biol Cons 112:63-85

Saetre P, Bååth E (2000) Spatial variation and patterns of soil microbial community structure in a mixed spruce-birch stand. Soil Biol Biochem 32:909-917

Schindler DW (1977) Evolution of phosphorus limitation in lakes. Science 195:260-262

Schonholzer F, Kohli L, Hahn D, Daniel O, Goez C, Zeyer J (1998) Effects of decomposition of leaves on bacterial biomass and on palatability to Lumbricus terrestris L. Soil Biol Biochem 30:1805-1813

Simons L, Allsopp N (2007) Rehabilitation of rangelands in Paulshoek, Namaqualand: understanding vegetation change using biophysical manipulations. J Arid Env 70:755-766

Staaf H, Berg B (1982) Accumulation and release of plant nutrients in decomposing Scots pine needle litter. Long term decomposition in a Scots pine forest II. Can J of Bot 60:1561-1568

Sterner RW, Elser JJ (2002) Ecological stoichiometry. Princeton University Press, Princeton

Stock WD, Allsopp N (1992) Functional perspective of ecosystems. In: Cowling RM (ed) The ecology of fynbos: nutrients, fire and diversity. Oxford University Press, Cape Town, pp 241-259

Stock WD, Lewis OAM (1986) Soil nitrogen and the role of fire as a mineralizing agent in a South African coastal fynbos ecosystem. J Ecol 74:317-328 
Sudderth EA, Stinson KA, Bazzaz FA (2005) Host-specific aphid population responses to elevated $\mathrm{CO} 2$ and increased $\mathrm{N}$ availability. Glob Chang Biol 11:1997-2008

Thuiller W, Midgley GF, Rouget M, Cowling RM (2006) Predicting patterns of plant species richness in megadiverse South Africa. Ecography 29:733-744

Todd SW, Hoffmann MT (1999) A fence-line contrast reveals effects of heavy grazing on plant diversity and community composition in Namaqualand, South Africa. Plant Ecol 142:169-178

Usher MB, Booth RG, Sparkes KE (1982) A review of progress in understanding the organization of communities of soil arthropods. Pedobiologia 23:126-144

Van der Lugt JJ, Schultz RA, Fourie N, Hon LJ, Jordaan P, Labuschagne L (1992) Galenia africana L. poisoning in sheep and goats: hepatic and cardiac changes. J Vet Res 59:323-333

Van Wilgen BW (2009) The evolution of fire and invasive alien plant management practices in fynbos. S Afr J Sci 105:335-342

van Wyk BE, van Oudtshoorn B, Gericke N (2000) Medicinal plants of South Africa, 2nd edn. Briza, Pretoria

Viketoft M, Sohlenius B, Palmborg C, Huss-Danell K, Bengtsson J (2005) Plant species effects on soil nematode communities in experimental grasslands. Appl Soil Ecol 30:90-103

Viketoft M, Bengtsson J, Sohlenius B, Berg MP, Petchey O, Palmborg C, Huss-Danell K (2009) Long-term effects of plant diversity and composition on soil nematode communities in grasslands. Ecology 90:90-99
Vitousek PM (2004) Nutrient cycling and limitation: Hawaii as a model system. Princeton University Press, Princeton

Vitousek PM, Howarth RW (1991) Nitrogen limitation on land and in the sea: how can it occur? Biogeochemistry 13:87-115

Vries FA, El Bitar H, Green LR, Klaasen JA, Mabulesa WT, Bodo B, Johnson Q (2005) An antifungal active extract from the aerial parts of Galenia africana. In: Midiwo JO, Yenesew A, Derese S (eds) 11th NAPRECA symposium book of proceedings, Antananarivo, Madagascar, 2005. Napreca, Nairobi, Kenya, pp 123-131. (http://www.napreca.net)

Wardle DA (2002) Communities and ecosystems: linking the aboveground and belowground components. Princeton University Press, Princeton

Wardle DA (2005) How plant communities influence decomposer communities. In: Bardgett RD, Usher MB, Hopkins DW (eds) Biological diversity and function in soils. Cambridge University Press, Cambridge, pp 119-138

Whitham TG, Young WP, Martinsen GD, Gehring CA, Schweitzer JA, Shuster SM, Wimp GM et al (2003) Community and ecosystem genetics: a consequence of the extended phenotype. Ecology 84:559-573

Witkowski ETF (1989) Effects of nutrient additions on litter production and nutrient return in a nutrient-poor Cape fynbos ecosystem. Plant Soil 117:227-235

Witkowski ETF (1991) Effects of invasive alien acacias on nutrient cycling in the coastal lowlands of the Cape fynbos. J Appl Ecol 28:1-15 